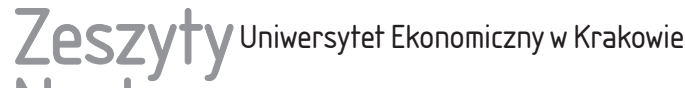 Naukowe
}

\section{Longitudinalne badania modeli biznesu przedsiębiorstw}

\section{Streszczenie}

Model biznesu staje się bytem ontologicznym często analizowanym w teorii oraz wykorzystywanym w praktyce zarządzania. Rozumiany wielorako jest wyzwaniem dla współczesnych badaczy. Istotna jest zatem odpowiedź na pytanie: jak badać model biznesu, jakie metody w tym celu zastosować? Według autora artykułu jedną z kluczowych metod mogących mieć zastosowanie w badaniu modeli biznesu są badania wzdłużne, zwane również longitudinalnymi. Celem artykułu jest przedstawienie opisu i interpretacji badań longitudinalnych jako należących do optymalnych metod badawczych stosowanych do badania modeli biznesu przedsiębiorstw.

Słowa kluczowe: badania longitudinalne, model biznesu, paradygmat, zarządzanie strategiczne.

Klasyfikacja JEL: M210.

\section{Wprowadzenie}

Paradygmaty zarządzania organizacjami z biegiem czasu ulegają dynamicznym zmianom. Zmiany te wpływają na powstawanie nowych bytów ontologicznych determinujących rozwój współczesnych przedsiębiorstw. Obecnie dysputy naukowe prowadzone są równolegle na poziomie teorii i praktyki zarządzania. Na poziomie teorii przeważa konceptualizacja, a na poziomie praktyki operacjonalizacja. Istotna jest odpowiednia konfiguracja teorii i praktyki w celu osiągnięcia ich wzajemnej synergii, kształtującej oczekiwaną wartość

Adam Jabłoński, Wyższa Szkoła Biznesu w Dąbrowie Górniczej, Katedra Zarządzania, 41-300 Dąbrowa Górnicza, ul. Cieplaka 1C, e-mail: adam.jablonski@ottima-plus.com.pl 
dla zarządzających przedsiębiorstwami menedżerów. Narzędziem będącym źródłem informacji strategicznej w zasadach podejmowania decyzji przez menedżerów są wyniki badań naukowych. To od ich jakości i implementacji zależy efektywność dynamicznie zarządzanych przedsiębiorstw. Istotne jest obecnie zagadnienie, co stanowi kluczowy obiekt badania w naukach o zarządzaniu oraz jakie metody badań są dla niego najbardziej potrzebne. Badacze, dysponując pewnym instrumentarium, poszukują optymalnych metod badań naukowych, aby odpowiadać na strategiczne pytania nauki stosowanej, tj. nauki o zarządzaniu. Owo instrumentarium osadzone jest między innymi w badaniach ilościowych, jakościowych, studium przypadku, eksperymentalnych, symulacyjnych, opartych na triangulacji i wzdłużnych. Jeśli chodzi o obiekt badania, w zarządzaniu strategicznym coraz większą rolę odgrywa koncepcja modeli biznesu. Model biznesu staje się bytem ontologicznym, który często jest analizowany w teorii oraz wykorzystywany w praktyce zarządzania. Rozumiany wielorako jest wyzwaniem dla współczesnych badaczy. Istotna jest zatem odpowiedź na pytania: Jak badać model biznesu? Jakie metody do tego celu zastosować? Według autora artykułu jedną z kluczowych metod mogących mieć zastosowanie w badaniu modeli biznesu są badania wzdłużne, zwane również longitudinalnymi. Celem artykułu jest przedstawienie podstawowych założeń tych badań. Można uznać, że należą do optymalnych metod badawczych modeli biznesu przedsiębiorstw.

\section{Model biznesu jako przedmiot badań w naukach o zarządzaniu}

Dynamika wykorzystania koncepcji modeli biznesu w teorii i praktyce współczesnego biznesu jest mocno zaskakująca. Szczególnie od 1995 r. zauważalny jest wzrost liczby publikacji naukowych, zarówno w światowych, jak i w lokalnych czasopismach naukowych. Jeszcze większy skok nastąpił po 2005 r. (zob. rys. 1).

Wynika stąd potrzeba wykorzystania badań naukowych między innymi do oceny efektywności tej koncepcji zarządzania.

Przedstawiając pojęcie modeli biznesu w ujęciu prowadzonych badań naukowych, należy przytoczyć kilka definicji określających złożoność omawianego zagadnienia w kontekście zmieniających się warunków prowadzenia biznesu. Jest to pojęcie różnie rozumiane i wykorzystywane - w tabeli 1 przedstawiono przegląd literatury dotyczącej koncepcji modeli biznesu. Ujęć modeli biznesu może być wiele, zatem także badania naukowe mogą mieć różny charakter.

Badania naukowe autora artykułu w zakresie modeli biznesu obecnie dotyczą między innymi:

1) paradygmatów mających zastosowanie w koncepcji modeli biznesu [Jabłoński 2014d, 2014f]; 
2) konfiguracji modeli biznesu w sytuacji kryzysu gospodarczego [Jabłoński 2014e];

3) typologii modeli biznesu - ujęcie sieciowe [Jabłoński 2013, s. 30; 2015a] i ujęcie systemowe [Jabłoński 2014b, Jabłoński i Jabłoński 2014a] itp.;

4) stabilności i trwałości [Jabłoński 2013], skalowalności [Jabłoński 2015b] i spójności [Jabłoński 2015c] modeli biznesu;

5) wpływu modeli biznesu na wzrost wartości przedsiębiorstwa lub destrukcję jego wartości [Jabłoński 2015a];

6) pomiaru zależności między kształtem modeli biznesu a kształtem strategii [Jabłoński 2014c];

7) badania modeli biznesu w cyklu życia przedsiębiorstwa [Jabłoński i Jabłoński 2013a, 2013b, 2014a].

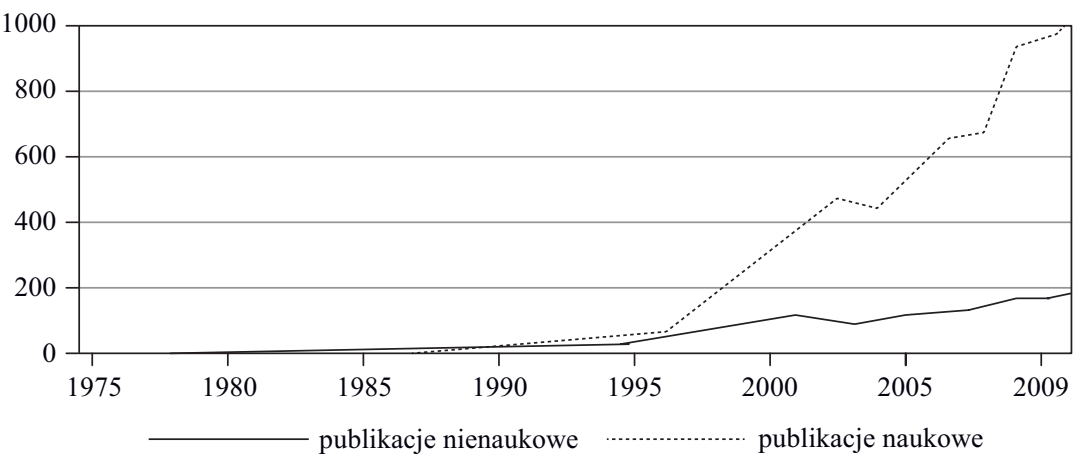

Rys. 1. Liczba publikacji zawierających wyrażenie business model w bazie EBSCO w latach 1975-2009

Źródło: [Zott, Amit i Massa 2010, s. 7].

Tabela 1. Przegląd literatury dotyczącej koncepcji modeli biznesu

\begin{tabular}{|l|l|}
\hline \multicolumn{1}{|c|}{$\begin{array}{c}\text { Podejście do rozumienia } \\
\text { modelu biznesu }\end{array}$} & \multicolumn{1}{c|}{ Autorzy i zagadnienia } \\
\hline $\begin{array}{l}\text { Model biznesu ujmowany z per- } \\
\text { spektywy łańcucha wartości }\end{array}$ & $\begin{array}{l}\text { K. Obłój [2010, s. 104-111] - operator, integrator, dyrygent } \\
\text { T. Gołębiowski, T.M. Dudzik, M. Lewandowska i M. Witek- } \\
\text {-Hajduk [2008] - tradycjonalista, gracz rynkowy, zlecenio- } \\
\text { biorca specjalista, dystrybutor, integrator }\end{array}$ \\
\hline E-model biznesu & $\begin{array}{l}\text { P. Timmers [1999] - e-sklep, e-zakupy, e-centrum handlowe, } \\
\text { e-aukcja, dostawca usług łańcucha wartości, wirtualna spo- } \\
\text { leczność biznesowa, platforma współpracy }\end{array}$ \\
\hline
\end{tabular}


cd. tabeli 1

\begin{tabular}{|c|c|}
\hline $\begin{array}{l}\text { Podejście do rozumienia } \\
\text { modelu biznesu }\end{array}$ & Autorzy i zagadnienia \\
\hline & $\begin{array}{l}\text { M. Rappa [2002] - reklama, filia, brokerstwo, społeczność, } \\
\text { infopośrednictwo, producent, handlowiec, subskrypcja, } \\
\text { użyteczność } \\
\text { L.M. Applegate [2000] - model dystrybucji skoncentrowanej } \\
\text { - detalista, rynek, agregator, pośrednik informacji; wymiana, } \\
\text { modele oparte na portalach - portale poziome; portale pio- } \\
\text { nowe; portale oparte na podobieństwie } \\
\text { modele produkcyjne - producent; usługodawca; edukator, } \\
\text { doradca; usługi w zakresie informacji i wiadomości, } \\
\text { modele oparte na zapewnianiu infrastruktury - pewna liczba } \\
\text { podmodeli, np. portale oparte na infrastrukturze }\end{array}$ \\
\hline $\begin{array}{l}\text { Model biznesu ujmowany przez } \\
\text { pryzmat rentowności przedsię- } \\
\text { biorstwa }\end{array}$ & $\begin{array}{l}\text { A. Slyvotzky, D.J. Morrison, B. Andelman [2000, s. } 66]- \\
22 \text { rentowne modele biznesu na bazie doświadczeń przedsię- } \\
\text { biorstw amerykańskich }\end{array}$ \\
\hline $\begin{array}{l}\text { Powiązanie modelu biznesu ze } \\
\text { strategią i procesami bizneso- } \\
\text { wymi }\end{array}$ & $\begin{array}{l}\text { A. Osterwalder i Y. Pigneur [2002], L. Bossidy i R. Charan } \\
\text { [2010], J. Niemczyk [2010, s. 203] }\end{array}$ \\
\hline $\begin{array}{l}\text { Typ modelu biznesu z perspek- } \\
\text { tywy kreowania wartości }\end{array}$ & $\begin{array}{l}\text { P.B. Seddon, G.P. Lewis, P. Freeman i G. Shanks [2004], } \\
\text { B. de Witt i R. Meyer [2007] }\end{array}$ \\
\hline $\begin{array}{l}\text { Rozpatrywanie modelu biznesu } \\
\text { z perspektywy interesariuszy }\end{array}$ & $\begin{array}{l}\text { F. Hoque [2002], S. Voelpel, M. Leibold, E. Tekie i G. von } \\
\text { Krogh [2005], A. Jabłoński [2008, s. 19] }\end{array}$ \\
\hline Sieciowe modele biznesu & $\begin{array}{l}\text { K. Perechuda [2013], A. Jabłoński i M. Jabłoński [2013c, } \\
\text { s. 30] }\end{array}$ \\
\hline $\begin{array}{l}\text { Powiązanie modelu biznesu } \\
\text { z podejściem zasobowym }\end{array}$ & K. Krzakiewicz, S. Cyfert [2011, s. 100-105] \\
\hline $\begin{array}{l}\text { Model biznesu zapewniający } \\
\text { stabilność i ciągłość funkcjono- } \\
\text { wania przedsiębiorstwa }\end{array}$ & $\begin{array}{l}\text { B. Demil i X. Lecocq [2010], K.D. Sandberg [2002], } \\
\text { A. Afuah i C. Tucci [2003] }\end{array}$ \\
\hline $\begin{array}{l}\text { Model biznesu rozpatrywany } \\
\text { z perspektywy rozwoju }\end{array}$ & B. Nogalski [2009] \\
\hline Hybrydowy model biznesu & $\begin{array}{l}\text { S.J. Deodhar, K. Saxena, R.K. Gupta i M. Ruohonen } \\
\text { [2012], A. Jabłoński [2015c] }\end{array}$ \\
\hline $\begin{array}{l}\text { Model zrównoważonego } \\
\text { biznesu }\end{array}$ & $\begin{array}{l}\text { W. Stubbs i C. Cocklin [2008], F. Boons i F. Lüdeke-Freund } \\
\text { [2013] i A. Jabłoński [2013] }\end{array}$ \\
\hline Geometryczny model biznesu & A. Neely i R. Delbridge [2007] \\
\hline
\end{tabular}

Źródło: opracowanie własne. 
Na modele biznesu przedsiębiorstw według wskazanych założeń należy spojrzeć w sposób holistyczny i eklektyczny. Podejście holistyczne pozwala na ocenę modelu biznesu w ujęciu wielowymiarowym, zarówno wertykalnym, jak i horyzontalnym. Te poziomy weryfikacji pozwalają kreować obraz modelu biznesu, wykorzystując jego pełny potencjał. Ujęcie eklektyczne wynika z możliwości czerpania komponentów modelu biznesu z wielu źródeł, przykładowo w ujęciu sieciowym z wielu sieci. Na omawiane zagadnienie należy także spojrzeć z uwzględnieniem wzajemnych relacji modelu biznesu ze strategią i procesami biznesowymi. Wtedy powstająca hybryda strategiczna służy poszukiwaniu wartości z każdego bytu ontologicznego, w tym przypadku z modelu biznesu, strategii i procesów biznesowych.

Na modele biznesu przedsiębiorstw można spojrzeć przez pryzmat zastosowania (biznes, zarządzanie publiczne). Zarówno klasyczny biznes, jak i zarządzanie publiczne wykorzystuje model biznesu w konceptualizacji i operacjonalizacji rozwiązań zarządczych, co pozwala na uniwersalizm tej koncepcji w naukach o zarządzaniu.

Rozpatrując model biznesu w aspekcie problemu badawczego, warto zwrócić uwagę, że podejmowany naukowy problem badawczy wyznaczający lukę badawczą powinien być sprawdzalny empirycznie, realny, prawidłowo „ustawiony” (czyli dobrze sformułowany), należycie uzasadniony i - co najważniejsze - dostosowany do możliwości intelektualnych, organizacyjnych i finansowych badacza. Właściwy dobór problemu naukowego jest efektem złożonego i zawsze w pełni świadomego procesu, w którym splatają się elementy obiektywne i subiektywne, intelektualne (rozumowe) i intuicyjne [Kuciński 2010, s. 89].

M. Lisiński twierdzi, że istotnym warunkiem skutecznego rozwiązania problemów każdego procesu badawczego jest zdefiniowanie wszystkich kategorii wyznaczających podstawę jego prowadzenia. Tak jest również w wypadku rozważań dotyczących metodologii nauk. Trzeba tu jednak zauważyć, że właśnie ta sfera każdej nauki ze znacznymi oporami poddaje się temu procesowi. Skutkuje to niekiedy brakiem podstawowych definicji czy stosowaniem pojęć, które nie uzyskały akceptacji w kręgach teoretyków i metodologów nauk lub dopiero torują sobie drogę, by wejść do zbioru powszechnie akceptowanych terminów [Lisiński 2010, s. 71].

Oceniając efektywność prowadzonych badań na tle oceny modeli biznesu, należy zwrócić także uwagę na następujące ograniczenia utrudniające pozyskanie danych do badań o dużej wiarygodności i jakości:

1) niepełna znajomość definicji i konstrukcji koncepcji modeli biznesu wśród polskich przedsiębiorców;

2) trudność rozróżnienia między modelem biznesu a strategią; 
3) nierozpatrywanie funkcjonowania przedsiębiorstwa w kontekście kreacji jego wartości, potencjalnej destrukcji wartości;

4) nierozpatrywanie modelu biznesu jako narzędzia do skalowania biznesu;

5) niewłaściwa forma prawna przedsiębiorstwa, niesprzyjająca wykorzystaniu pełnego potencjału tkwiącego w naukach o zarządzaniu (forma samozatrudnienia, prowadzenie działalności gospodarczej w formie jednoosobowej działalności gospodarczej, spółki cywilnej, spółki jawnej);

6) brak zdefiniowania lub trudności w jasnym określeniu podstawowego celu prowadzenia przedsiębiorstwa (wzrost zysku, wzrost krótkoterminowej lub długoterminowej wartości przedsiębiorstwa, szybka sprzedaż przedsiębiorstwa np. w wyniku problemów z sukcesją, wartość dla interesariuszy itp.);

7) problemy menedżerów w ujęciu swojego modelu biznesu w ramy teoretyczne nauk o zarządzaniu (nadużywanie stwierdzeń w kontekście traktowania pojęć modeli biznesu jako tzw. podejścia akademickiego do zarządzania).

To tylko wybrane problemy utrudniające prowadzenie badań w zakresie modeli biznesu, niemniej jednak istotne w obecnym kształcie polskiego rynku gospodarczego.

\section{Paradygmaty w koncepcji modeli biznesu}

Dokonując analizy mechanizmów dotyczących badań modeli biznesu, nie sposób nie omówić podejścia do paradygmatów w naukach o zarządzaniu z perspektywy bytu ontologicznego, jakim jest model biznesu.

W systemowej teorii organizacji modele pełnią wszystkie podstawowe funkcje poznawcze: opisu, wyjaśniania, heurystyczne i projektowe. Funkcja opisu polega na przypisaniu konkretnemu obiektowi lub procesowi pewnych cech i odwzorowaniu tego za pomocą modelu [Koźmiński i Latusek-Jurczak 2011, s. 48]. Jak twierdzi J. Rokita, w zależności od rodzaju sytuacji problemowej każde podejście systemowe jest przydatne, a centralną kwestią myślenia systemowego jest pluralizm metodologiczny. Pluralizm może być osiągnięty dzięki zastosowaniu metodologii wyrosłych z ich paradygmatów. Pluralizm respektuje różne nurty myślenia systemowego, powodując rozwój teorii, i poszerza możliwości wykorzystania tego myślenia w praktyce menedżerskiej [Rokita 2011, s. 247]. Według W. Czakona paradygmat sieciowy wychodzi z obserwacji rzeczywistości społecznej i gospodarczej. Przedsiębiorstwa funkcjonują w otoczeniu o relatywnie niewielkiej liczbie aktorów, z którymi są połączone więziami zmieniającymi się w czasie. Tymi aktorami są zwykle dostawcy, konkurenci i klienci. Sam proces tworzenia wartości, a następnie jej dostarczania angażuje pewien zbiór aktorów, z których każdy dąży do osiągnięcia indywidualnych celów. Równocześnie jednak przedsiębiorstwo przyczynia się do osiągania celów zbiorowych 
tej zbiorowości, z którą wiążą go relacje współzależności [Czakon 2012, s. 25]. Według A. Jakiego w paradygmacie sieciowym następuje wzmocnienie równocześnie oddziaływania efektu synergii, dzięki tworzeniu sojuszy umożliwiających pozyskiwanie lub kreowanie nowych zasobów gospodarczych oraz powstawanie systemów ekonomicznych trudnych do imitacji, cechujących się bowiem bardzo wysokim stopniem złożoności, a tym samym i niepowtarzalności. W tym kontekście paradygmat sieciowy nawiązuje do paradygmatu systemowego i stanowi jego dalsze rozwinięcie [Jaki 2014, s. 11].

Interesujące ujęcie dotyczące zależności zachodzącej między siecią a systemem przedstawił A. Płoszaj. Pojęcie sieci jest związane z teorią systemów. „Definicje sieci i systemu są bardzo podobne. (...) System, podobnie jak sieć, składa się z elementów oraz zachodzących między nimi relacji. Jednakże pojęcia sieci i systemu nie są tożsame. System jest pojęciem szerszym, tzn. każda sieć może być rozpatrywana jako system. W podejściu sieciowym rozpatruje się zazwyczaj elementy tego samego rodzaju, np. osoby (sieć jednomodalna), znacznie rzadziej dwa typy elementów (sieć dwumodalna). Analizy sieci wielomodalnych są bardzo rzadkie, przede wszystkim ze względu na skomplikowanie obliczeń. W analizie sieci bierze się pod uwagę określony typ relacji. (...). Natomiast podejście systemowe obejmuje wiele rodzajów elementów oraz wszelkie typy łączących je relacji. (...) Podejście systemowe cechuje swoisty holizm. Natomiast w podejściu sieciowym bierze się pod uwagę określony rodzaj elementów oraz relacji między nimi. (...). Podejście sieciowe jest zatem znacznie skromniejsze niż podejście systemowe. Zaletę ograniczenia zakresu analizy w podejściu sieciowym stanowi możliwość stosowania metod ilościowych, których często nie da się wykorzystać w podejściu systemowym, zwłaszcza w odniesieniu do zjawisk społecznych" [Płoszaj 2013, s. 32-33]. A. Jaki uważa, że prowartościowy paradygmat staje się w tej sytuacji ramowym wzorcem wytyczającym orientację na wartość (prowartościową orientację) jako nową w zarządzaniu przedsiębiorstwem. Orientację tę można traktować jako jeden ze składników orientacji na wyniki. Akcentuje ona bowiem zarobkowy charakter przedsiębiorstwa i związaną z tym potrzebę przestrzegania zasady gospodarności jako podstawy przetrwania i rozwoju przedsiębiorstwa na rynku [Jaki 2011, s. 11]. Determinantami wartości przyczyniającymi się do osiągania wyników przez przedsiębiorstwo mogą być: stopa wzrostu przychodów netto ze sprzedaży, marża zysku operacyjnego, inwestycje w aktywa trwałe, inwestycje w kapitał obrotowy, stopa podatku dochodowego, przewaga konkurencyjna, koszt kapitału [Copeland i Weston 1988, s. 384-386].

Rozpatrując wieloparadygmatyczność, należy zacytować Ł. Sułkowskiego, który twierdzi, że strategia „pluralizmu epistemologicznego”, zbliżona do „podejścia godziny 10 ” K. Weicka, zakłada możliwość łączenia podejść zaczerpniętych z różnych paradygmatów, ale pod warunkiem dążenia do spójnych rezultatów poznawczych. Sugerowana jest również kolista interpretacja procesu badań. 
Mogą zatem być wykorzystane pojęcia funkcjonalistyczne (hipotezy, weryfikacja lub falsyfikacja) oraz interpretatywne (znaczenie, interpretacja), a nawet krytyczne (np. fałszywa świadomość). Metodyka badań ma prowadzić do komplementarności (triangulacja metodologiczna) i zakłada możliwość łączenia metod ilościowych i jakościowych, w tym również metod zaangażowanych. Strategia „eklektyzmu epistemologicznego" zakłada podobnie jak pluralizm możliwość łączenia teorii i metod zaczerpniętych z różnych paradygmatów.

Chodzi zatem nie tylko o wieloparadygmatyczność, ale również o zdolność przedsiębiorstw do budowania platformy niezbędnej do wykorzystania teorii, metod i koncepcji zarządzania dla funkcji wyznaczonego przez przedsiębiorstwo celu. Przy założeniu, że istotne staje się zbudowanie systemu paradygmatów, można przyjąć, że ową skuteczną platformą niezbędną do efektywnego zarządzania przedsiębiorstwem jest jego model biznesu. W tym przypadku zderza się eklektyzm epistemologiczny z eklektyzmem występującym w modelach biznesu.

$\mathrm{W}$ tabeli 2 przedstawiono atrybuty modelu biznesu w teorii nauk o zarządzaniu wynikające z opisanych wcześniej paradygmatów.

Tabela 2. Atrybuty modelu biznesu w teorii nauk o zarządzaniu

\begin{tabular}{|c|l|}
\hline Lp. & \multicolumn{1}{|c|}{ Atrybuty modelu biznesu w teorii nauk o zarządzaniu } \\
\hline 1 & Prosty lub złożony \\
\hline 2 & Charakter ewolucyjny lub rewolucyjny modelu biznesu \\
\hline 3 & Model atomistyczny lub model sieciowy \\
\hline 4 & Układ komponentowy lub zwarty, jednolity model biznesu \\
\hline 5 & Model statyczny lub dynamiczny \\
\hline 6 & W początkowej fazie rozwoju lub dojrzały, schyłkowy \\
\hline 7 & Dążący do równowagi lub chaosu \\
\hline
\end{tabular}

Źródło: opracowanie własne.

Tabela 3. Wybrane paradygmaty w koncepcji modeli biznesu

\begin{tabular}{|l|l|l|l|l|}
\hline \multicolumn{1}{|c|}{ Cecha } & \multicolumn{1}{|c|}{$\begin{array}{c}\text { Paradygmat } \\
\text { systemowy }\end{array}$} & \multicolumn{1}{|c|}{$\begin{array}{c}\text { Paradygmat } \\
\text { sieciowy }\end{array}$} & $\begin{array}{c}\text { Paradygmat } \\
\text { prowartościowy }\end{array}$ & $\begin{array}{c}\text { Wielopara- } \\
\text { dygmatyczność }\end{array}$ \\
\hline Podejście & $\begin{array}{l}\text { liniowe, atomi- } \\
\text { styczne }\end{array}$ & $\begin{array}{l}\text { wertykalne } \\
\text { i horyzontalne }\end{array}$ & liniowe & eklektyczne \\
\hline $\begin{array}{l}\text { Relacje } \\
\text { z otoczeniem }\end{array}$ & $\begin{array}{l}\text { spójność modelu } \\
\text { biznesu z otocze- } \\
\text { niem }\end{array}$ & $\begin{array}{l}\text { model biznesu } \\
\text { jest w sieci i jest } \\
\text { częścią sieci }\end{array}$ & $\begin{array}{l}\text { spójność modelu } \\
\text { biznesu z otocze- } \\
\text { niem }\end{array}$ & $\begin{array}{l}\text { pełna wielowy- } \\
\text { miarowość }\end{array}$ \\
\hline Perspektywa & holistyczna & holistyczna & celowa & holistyczna \\
\hline Struktura & płaska & węzłowa & płaska & geometryczna \\
\hline Układ & symetryczny & symbiotyczny & symetryczny & synergiczny \\
\hline
\end{tabular}

Źródło: opracowanie własne. 
Tabela 3 opisuje cechy poszczególnych, wybranych paradygmatów mających zastosowanie w koncepcji modeli biznesu.

\section{Logika badań naukowych modeli biznesu}

Dokonując analizy epistemologicznych i metodologicznych założeń nauk o zarządzaniu w kontekście koncepcji modeli biznesu, można przyjąć, że wymiar teoretyczny opracowanych modeli biznesu jest ulokowany w teorii średniego zasięgu w rozumieniu R.K. Mertona [1968]. Teorie średniego zasięgu proponują ograniczone warunkami społecznymi i historycznymi uogólnienia, które jednak poddawane są procesowi weryfikacji lub falsyfikacji charakterystycznej dla neopozytywizmu [Sułkowski 2012, s. 96].

W trakcie przygotowywania operatu badawczego do oceny modeli biznesu można wykorzystać założenia 8-elementowego modelu tworzenia teorii naukowej R. Dubina [Dubin 1983] obejmującego:

1) zdefiniowanie jednostek teorii, a więc podstawowych elementów, które będą wchodziły w zależności w badanym procesie;

2) opisanie relacji i zasad, na których opierają się związki pomiędzy jednostkami teorii;

3) wskazanie granic teorii pozwalających na skupienie się w procesie wyjaśniania rzeczywistości na najważniejszych siłach i związkach oraz demarkację z innymi teoriami;

4) wywnioskowanie stanów systemu, a więc tego, jak system się zachowuje, gdy działają określone siły i zachodzą związki pomiędzy jednostkami teorii;

5) zaproponowanie modelu teoretycznego logicznie i spójnie opisującego relacje przyczynowo-skutkowe;

6) operacjonalizacja modelu, tzn. znalezienie wskaźników empirycznych, które mogą być testowane i mierzone;

7) postawienie hipotez lub pytań badawczych pozwalających na ustalenie stanu wskaźników empirycznych w procesie testowania;

8) testowanie, a więc weryfikowanie hipotez lub próba odpowiedzi na postawione pytania badawcze.

Podejmując się badania między innymi w koncepcji modeli biznesu, badacz formułuje hipotezę lub hipotezy naukowe, które organizują czynności zmierzające do odkrycia prawdy. Hipoteza jest wstępnym twierdzeniem (przypuszczeniem naukowym), opartym na prawdopodobieństwie. Dotyczy rzeczywistości (stanów, zjawisk lub procesów), które będą przedmiotem badania i mają na celu odkrycie (objaśnienie) nieznanych zjawisk, ustalenie nieznanych dotąd praw. Hipotezy naukowe ukierunkowują badanie, a ono samo sprowadza się przede 
wszystkim do ich weryfikacji. Hipotezę uważa się za udowodnioną, gdy badania potwierdzają jej zgodność z faktami. Wówczas wynikom można przypisać status wiedzy naukowej. Przeciwieństwem jest obalenie (falsyfikacja) hipotezy, stwierdzenie jej fałszywości. Praca naukowa nie może się ograniczyć do postawienia hipotez, nie może w niej zabraknąć ustosunkowania się do nich [Kuc 2012, s. 166]. Przyjmując takie stwierdzenia jako wyjściowe w przeprowadzeniu badań naukowych zgodnie ze sztuką, należy dokonać wielowymiarowej analizy służącej do zapewnienia zgodności przeprowadzonych badań z przyjętymi standardami gwarantującymi poprawność metodologiczną przeprowadzonych badań naukowych. Pierwszym krokiem jest wyznaczenie warunków brzegowych związanych z falsyfikacją i weryfikacją postawionych hipotez. Pojęcie falsyfikacjonizmu rozpatruje się często zgodnie z przyjętą definicją K. Poppera, który uznał, że falsyfikacjonizm oznacza, iż choć nie da się udowodnić prawdziwości danego twierdzenia nauki, to można je obalić, czyli sfalsyfikować. Twierdzenia i teorie naukowe będą miały cechę falsyfikowalności, a więc będą potencjalnie do obalenia [Kuc 2012, s. 126]. Oficjalny postulat falsyfikowalności K. Poppera mówi, że reguły metody empirycznej projektować należy w taki sposób, aby nie chroniły żadnego twierdzenia nauki przed falsyfikacją [Popper 1977, s. 50]. W. Czakon zauważa przy tym, że problem polega nie tylko na tym, iż nie można dowieść prawdziwości żadnego twierdzenia, lecz jedynie je sfalsyfikować. Dotyczy to również sposobu prowadzenia badań empirycznych i tworzenia na ich podstawie pojedynczych twierdzeń oraz całych teorii, czyli problemów metod badawczych [Czakon 2006, s. 9]. Przyjęcie założenia opracowanego przez Ł. Sułkowskiego, że weryfikacjonizm pozwala na trwałe stwierdzenie wartości poznawczej danych stwierdzeń przez zastosowanie badań empirycznych przedmiotu, daje możliwość jednoznacznej odpowiedzi na pytanie, czym jest organizacja i jakie są jej własności oraz w jaki sposób nimi efektywnie zarządzać [Sułkowski 2012, s. 125]. Do określenia zasad formułowania hipotez można wykorzystać założenia opracowane przez K. Kucińskiego. Mówi on, że formułując hipotezy badawcze, stawia się na ogół tzw. hipotezę główną oraz kilka związanych z nią hipotez roboczych, stanowiących jej logiczne uszczegółowienie, jednakże każda z nich powinna być traktowana w sposób indywidualny, ponieważ ma swój specyficzny charakter związany z celem badania i z jego tezą. Stopień ogólności formułowanych hipotez badawczych zależy wyłącznie od zakresu postawionego problemu badawczego. Oznacza to, że problem badawczy, teza badawcza i hipotezy badawcze są ze sobą ściśle powiązane i że musi to znajdować swoje odzwierciedlenie w procesie realizacji danego badania i pisemnego opracowania jego wyników [Kuciński 2010, s. 94-95]. 


\section{Koncepcja badań longitudinalnych modeli biznesu przedsiębiorstw}

Badania dynamiki procesów organizacyjnych i zarządczych ze swej natury powinny mieć charakter longitudinalny. $\mathrm{W}$ takich badaniach poszukiwanie mechanizmów zmiany staje się ważniejsze dla zrozumienia procesu w miejsce określania stadiów rozwoju [Stańczyk-Hugiet 2014, s. 47].

Bardzo trudno jest wnioskować o działalności organizacji, patrząc na migawki z badania najróżniejszych organizacji. Bardziej wartościowe poznawczo jest przyjrzenie się kilku z nich w działaniu, temu, jak ich części współzależą od siebie z perspektywy ich stanu początkowego i końcowego. W ten sposób możemy odróżniać elementy zmieniające się i statyczne, a taka wiedza jest niezbędna dla każdego badacza. Teoretycy zdają sobie z tego sprawę, co wyraża się w co najmniej jednym poziomie teoretyzowania, a mianowicie próbami lokowania swoich teorii $\mathrm{w}$ ujęciu dynamicznym, lecz niestety często z tendencją do poddawania badaniu tylko danych przekrojowych (cross-sectional), na podstawie których są generowane i testowane teorie [Stańczyk-Hugiet 2014, s. 54]. Według J.R. Kimberly [1976, s. 321-348] wzdłużne badania naukowe składają się z tych technik, metodologii i działań, które umożliwiają obserwację, opis i (lub) klasyfikację zjawisk organizacyjnych w taki sposób, że procesy mogą zostać zidentyfikowane i empirycznie udokumentowane. Wzdłużne badanie zasadniczo bada procesy w wielu okresach. Ponieważ czas trwania pomiędzy działaniami gromadzenia danych jest określony przez badacza, to liczba okresów gromadzenia danych jest odmienna według różnych wzorów. Badania wzdłużne projektuje się, zmieniając sześć parametrów: długość badań, czas pomiędzy działaniami zbierania danych, liczbę okresów zbierania danych, metodę zbierania danych, cele badań oraz podmiot analizy [Venkatesh i Vitalari 1991, s. 115-144]. C. Janson sugeruje dwie szerokie klasy badania wzdłużnego: współzależne badania wzdłużne (w tym badania zarówno zwykłych populacji reprezentatywnych, jak i reprezentatywnych ludności) i badania eksperymentalne [Janson 1981]. Wzdłużne badania związane są z realizacją powtarzalnych pomiarów tej samej populacji osobników od dłuższego czasu, to znaczy w czasie, który pozwala na wykrycie zmian. Wzdłużne badanie jest często nazywane badaniem prospektywnym. Istotną cechą badań wzdłużnych jest to, że jednostka dokonuje pomiarów kilka razy w czasie. Badania wzdłużne kontrastują z badaniami poprzecznymi, w których pomiar dla każdej jednostki jest pojedynczy, to jest w jednym punkcie czasowym, chociaż często jest tak, że te same pytania badawcze można stawiać w badaniu poprzecznym i w badaniu wzdłużnym, ale główną zaletą pierwszych z nich jest zdolność do rozdzielenia różnych typów zmian. Analiza danych wzdłużnych w modelowaniu statystycznym wyróżnia się szczególnymi własnościami, do których zalicza się m.in. [Frątczak 2014, s. 81-133]: 
1) możliwość kontroli heterogeniczności dla poszczególnych jednostek;

2) więcej informacji o danych: większa zmienność, mniej współliniowości, więcej stopni swobody i większa efektywność;

3) lepsza zdolność do badania dynamiki zjawiska, np. na podstawie badania przekrojowego można powiedzieć, jaki jest procent osób bezrobotnych, ale na podstawie badania wzdłużnego można określić podział okresów bezrobocia;

4) możliwość identyfikacji i pomiaru efektów, które nie są wykrywalne w badaniu przekrojowym lub w tradycyjnej analizie szeregów czasowych;

5) możliwość budowy i testowania bardziej złożonych modeli zachowań (behawioralnych) niż z danych badań przekrojowych czy szeregów czasowych;

6) unikanie nieobiektywnej agregacji - wynika to z faktu, że większość danych wzdłużnych są to zbiory na poziomie mikro danych, ale włączane są też różne struktury danych (hierarchiczne i niehierarchiczne);

7) możliwość kontroli nieobserwowanych zmiennych oraz możliwość badania efektu przyczynowości (causality mechanism).

W tabeli 4 opisano różnice między badaniem wzdłużnym i poprzecznym.

Tabela 4. Różnice między badaniami wzdłużnymi i poprzecznymi

\begin{tabular}{|l|l|l|}
\hline \multicolumn{1}{|c|}{ Cecha } & \multicolumn{1}{|c|}{$\begin{array}{c}\text { Badania wzdłużne- } \\
\text { longitudinalne }\end{array}$} & \multicolumn{1}{|c|}{$\begin{array}{c}\text { Badania poprzeczne } \\
- \text { cross sectional }\end{array}$} \\
\hline Częstotliwość badania & wielokrotna & pojedyńcza \\
\hline Podmiot & ten sam & wiele podmiotów \\
\hline Metody i narzędzia & różnorodne & najczęściej wystandaryzowane \\
\hline Badacz & $\begin{array}{l}\text { bardzo dobrze znający badany } \\
\text { podmiot }\end{array}$ & $\begin{array}{l}\text { często posiadający ograni- } \\
\text { czoną wiedzę o podmiotach }\end{array}$ \\
\hline Dane & wielokryterialne & ustrukturalizowane \\
\hline Orientacja & $\begin{array}{l}\text { związki przyczynowo-skut- } \\
\text { kowe w ramach zmiany }\end{array}$ & mniej klarowne \\
\hline Populacja & niecałkowita & $\begin{array}{l}\text { łączenie podmiotów w próbie } \\
\text { głównie dla korelacji linio- } \\
\text { wych }\end{array}$ \\
\hline Okres obserwacji & długookresowy & punktowy \\
\hline
\end{tabular}

Źródło: opracowanie własne na podstawie: [Stańczyk-Hugiet 2014, s. 47].

W badaniu wzdłużnym w kontekście modeli biznesu autor niniejszego artykułu analizuje związki przyczynowo-skutkowe występujące w konceptualizacji i operacjonalizacji obserwowanych modeli biznesu. Przyczyna i skutek powiązań może dotyczyć głównie atrybutów (komponentów) modeli biznesu badanych firm. Wydarzenia ważne dla rozwoju procesów zmian i rozwoju modeli biznesowych spółki i ich atrybutów zostały przez autora zidentyfikowane i zbadane. Pozwalają one zrozumieć i wyjaśnić procesy zmian konfiguracji modelu biznesu. Rozważania zawarte w wynikach badań są oparte między innymi na własnych 
obserwacjach autora na temat rzeczywistych modeli biznesowych w praktyce gospodarczej. Dlatego można je stosować jako punkt odniesienia dla własnych mechanizmów zarządzania stosowanych przez menedżerów w zakresie projektowania i operacjonalizacji zrównoważonych modeli biznesu przedsiębiorstw.

Opracowany zestaw następujących zasad może mieć zastosowanie do oceny modelu biznesu z wykorzystaniem badań longitudinalnych:

1) długa obserwacja modelu biznesu pozwala na ocenę jego rewolucji lub ewolucji;

2) częstotliwość badania może umożliwiać korektę modelu biznesu w poszczególnych fazach funkcjonowania przedsiębiorstwa;

3) obserwacja badacza może wyznaczać powstawanie zdolności modelu biznesu do skalowalności;

4) obserwacja wpływa pozytywnie na dobór atrybutów modelu biznesu adekwatnych do potrzeb;

5) badania naukowe mają charakter proaktywny, informując nie tylko o przeszłości, ale także o przyszłości rozwoju modelu biznesu.

\section{Podsumowanie}

Koncepcja modeli biznesu jest już mocno osadzona w teorii i praktyce nauk o zarządzaniu. Trwają poszukiwania optymalnych metod badania modeli biznesu rozpatrywanych z różnych perspektyw. Te perspektywy kształtują mechanizmy wyboru badań naukowych i stanowią determinantę osiąganych z nich wyników. Można przyjąć, że jedną z metod badawczych mogących obecnie mieć szerokie zastosowanie w badaniach modeli biznesu będą badania longitudinalne. Ich wykorzystanie może pozytywnie wpłynąc na zasady konceptualizacji i operacjonalizacji modeli biznesu w ujęciu pozyskanych wyników badań naukowych.

\section{Literatura}

Afuah A., Tucci C. [2003] Biznes internetowy. Strategie i modele, Oficyna Ekonomiczna, Kraków.

Applegate L.M. [2000], E-business Models: Making Sense of the Internet Business Landscape [w:] Information Technology and the New Enterprise: Future Models for Managers, eds L.M. Applegate, G.W. Dickson, G. DeSanctis, Prentice Hall, Upper Saddle River.

Boons F., Lüdeke-Freund F. [2013], Business Models for Sustainable Innovation: State-of-the-art and Steps towards a Research Agenda, „Journal of Cleaner Production”, vol. 45, https://doi.org/10.1016/j.jclepro.2012.07.007.

Bossidy L., Charan R. [2010], Szósty zmyst w zarządzaniu firma. Tworzenie wykonalnych planów i modeli biznesowych, MT Biznes, Warszawa. 
Copeland T., Weston J.F. [1988], Financial Theory and Corporate Policy, Addison-Wesley, Reading.

Cyfert S., Krzakiewicz K. [2011], Wykorzystanie koncepcji modeli biznesu w zasobowej teorii firmy [w:] Rozwój szkoły zasobowej zarządzania strategicznego, red. R. Krupski, Prace Naukowe Wałbrzyskiej Wyższej Szkoły Zarządzania i Przedsiębiorczości, Wałbrzych.

Czakon W. [2006], Łabędzie Poppera - case studies w badaniach nauk o zarzadzaniu, „Przegląd Organizacji”, nr 9.

Czakon W. [2012], Sieci w zarzadzaniu strategicznym, Oficyna a Wolters Kluwer business, Warszawa.

De Witt B., Meyer R. [2007], Synteza strategii. Tworzenie strategii konkurencyjnej przez tworzenie paradoksów, Polskie Wydawnictwo Ekonomiczne, Warszawa.

Demil B., Lecocq X. [2010], Business Model Evolution: In Search of Dynamic Consistency, „Long Range Planning”, 43(2-3), https://doi.org/10.1016/j.lrp.2010.02.004.

Deodhar S.J., Saxena K., Gupta R.K., Ruohonen M. [2012], Strategies for Software-based Hybrid Business Models, ,Journal of Strategic Information Systems” 21(4), https://doi. org/10.1016/j.jsis.2012.06.001.

Dubin R. [1983], Theory Building in Applied Areas [w:] Handbook of Industrial and Organizational Psychology, ed. M.D. Dunnette, Wiley, New York.

Frątczak E. [2014], Analiza danych wzdtużnych - wybrane zagadnienia, „Statystyka zastosowania biznesowe i społeczne", Wydawnictwo Wyższej Szkoły Menedżerskiej w Warszawie, Warszawa.

Gołębiowski T., Dudzik T.M., Lewandowska M., Witek-Hajduk M. [2008], Modele biznesu polskich przedsiębiorstw, Szkoła Główna Handlowa, Warszawa.

Hoque F. [2002], The Alignment Effect: How to Get Real Business Value out of Technology, Financial Times/Prentice Hall.

Jabłoński A. [2008], Modele biznesu w sektorach pojawiajacych się i schytkowych. Tworzenie przewagi konkurencyjnej przedsiębiorstwa opartej na jakości i kryteriach ekologicznych, Wydawnictwo Wyższej Szkoły Biznesu w Dąbrowie Górniczej, Dąbrowa Górnicza.

Jabłoński A. [2013], Modele zrównoważonego biznesu w budowie długoterminowej wartości przedsiębiorstw z uwzględnieniem ich społecznej odpowiedzialności, Difin, Warszawa.

Jabłoński A. [2014a], Model biznesu i strategia w osiaganiu przewag konkurencyjnych przedsiębiorstw - ujęcie wielowymiarowe [w:] Współczesne trendy $i$ wyzwania w zarządzaniu wartościa przedsiębiorstw, red. M. Jabłoński, Wyższa Szkoła Biznesu w Dąbrowie Górniczej, Dąbrowa Górnicza.

Jabłoński A. [2014b], Myślenie systemowe i sieciowe w konstruowaniu modeli biznesu, „Kwartalnik Nauk o Przedsiębiorstwie”, nr 2.

Jabłoński A. [2014c], Paradygmat systemowy, sieciowy i prowartościowy a konstruowanie modeli zrównoważonego biznesu przedsiębiorstw, „Ekonomika i Organizacja Przedsiębiorstwa", nr 10.

Jabłoński A. [2014d], Paradygmaty w modelach zrównoważonego biznesu a kreowanie wartości przedsiębiorstwa, „Przegląd Organizacji”, nr 6.

Jabłoński A. [2014e], Sustainable Capital Market and the Attributes of Business Models in the Crisis, „Przegląd Organizacji”, nr 1.

Jabłoński A. [2014f], Wieloparadygmatyczność w zarządzaniu a trwałość modelu biznesu przedsiębiorstwa, Studia i Prace Kolegium Zarządzania i Finansów, Zeszyt Naukowy nr 139, Szkoła Główna Handlowa, Warszawa. 
Jabłoński A. [2015a], Economization of Networking Business Models of the Enterprises - Management of Network Organizations - Theoretical Problems and Dilemmas in Practice, eds W. Sroka, Š. Hittmár, Springer.

Jabłoński A. [2015b], Skalowalność modeli biznesu w środowisku sieciowym, Difin, Warszawa.

Jabłoński A. [2015c], Spójność hybrydy strategicznej w środowisku sieciowym, Difin, Warszawa.

Jabłoński A., Jabłoński M. [2013a], Cykl życia wartości przedsiębiorstw wobec kondycji modelu biznesu, „Kwartalnik Nauk o Przedsiębiorstwie”, nr 4.

Jabłoński A., Jabłoński M. [2013b], Modele biznesu w cyklu życia przedsiębiorstwa wyzwania strategiczne, „Przegląd Organizacji”, nr 9.

Jabłoński A., Jabłoński M. [2013c], Projektowanie sieciowych modeli biznesu, „Ekonomika i Organizacja Przedsiębiorstwa”, nr 12.

Jabłoński A., Jabłoński M. [2014a], Atrybuty modeli biznesu a cykl życia przedsiębiorstwa, „Organizacja i Kierowanie”, nr 4.

Jabłoński A., Jabłoński M. [2014b], System zarzadzania a atrybuty modeli biznesu, „Problemy Jakości”, nr 4.

Jaki A. [2011], Orientacja na wartość w zarzadzaniu przedsiębiorstwem, „Przegląd Organizacji”, nr 9.

Jaki A. [2014], Mechanizmy rozwoju paradygmatów zarządzania, „Przegląd Organizacji”, nr 2.

Janson C. [1981], Some Problems of Longitudinal Research in the Social Sciences [w:] Longitudinal Research: Methods and Uses in Behavioral Science, eds F. Schulsinger, S. Mednick, J. Knop, Martinus Nijhoff Publishing, Boston.

Koźmiński A.K., Latusek-Jurczak D. [2011], Relacje międzyorganizacyjne w naukach o zarzadzaniu, Oficyna a Wolters Kluwer business, Warszawa.

Kuc B.R. [2012], Funkcje nauki. Wstęp do metodologii. Nauka nie jest gra, Wydawnictwo PTM, Warszawa.

Kuciński K. [2010], Problemy badawcze w naukach ekonomicznych [w:] Metodologia nauk ekonomicznych. Dylematy $i$ wyzwania, red. K. Kuciński, Difin, Warszawa.

Lisiński M. [2010], Model formułowania współczesnej koncepcji zarządzania [w:] Osiagnięcia i perspektywy nauk o zarządzaniu, red. S. Lachiewicz, G. Nogalski, Wolters Kluwer, Warszawa.

Merton R.K. [1968], Social Theory and Social Structure, Free Press, New York.

Metodologia nauk ekonomicznych. Dylematy i wyzwania [2010], red. K. Kuciński, Difin, Warszawa.

Neely A., Delbridge R. [2007], Effective Business Models: What Do They Mean for Whitehall, www.nationalschool.gov.uk/sunningdaleiinstitute.

Niemczyk J. [2010], Modele biznesowe [w:] Zarzadzanie. Kanony i trendy, red. M. Morawski, J. Niemczyk, K. Perechuda, E. Stańczyk-Hugiet, C.H. Beck, Warszawa.

Nogalski B. [2009], Modele biznesu jako narzędzia reorientacji strategicznej przedsiębiorstw, Referat wygłoszony na posiedzeniu Komitetu Nauk Organizacji i Zarządzania PAN, Warszawa.

Obłój K. [2010], Pasja i dyscyplina strategii. Jak z marzeń i decyzji zbudować sukces firmy, Poltext, Warszawa.

Osterwalder A., Pigneur Y. [2002], An e-Business Model Ontology for Modeling e-Business, 15th Blend Electronic Commerce Conference e-Reality: Constructing the e-Economy, Slovenia, 17-19 June 2002. 
Perechuda K. [2013], Dyfuzja wiedzy w przedsiębiorstwie sieciowym. Wizualizacja i kompozycja, Wydawnictwo Uniwersytetu Ekonomicznego we Wrocławiu, Wrocław.

Płoszaj A. [2013], Sieci instytucji otoczenia biznesu, Wydawnictwo Naukowe Scholar, Warszawa.

Popper K. [1977], Logika odkrycia naukowego, wyd. 1, Wydawnictwo Naukowe PWN, Warszawa.

Popper K. [2002], Logika odkrycia naukowego, wyd. 2, Wydawnictwo Naukowe PWN, Warszawa.

Rappa M. [2002], Managing the Digital Enterprise: Business Models on the Web, http:// digitalenterprise.org/models/models.html.

Rokita J. [2011], Myślenie systemowe w zarzadzaniu organizacjami, Prace Naukowe Uniwersytetu Ekonomicznego w Katowicach, Katowice.

Sandberg K.D., [2002] Is It Time to Trade in Your Business Model?, „Harvard University Update", January.

Seddon P.B., Lewis G.P., Freeman P., Shanks G. [2004], The Case for Viewing Business Models as Abstractions of Strategy, „Communications of the Association for Information Systems", vol. 13.

Slyvotzky A.J., Morrison D.J., Andelman B. [2000], Strefa zysku, PWE, Warszawa.

Stańczyk-Hugiet E. [2014], Badania longitudinalne w zarządzaniu, czyli jak dostrzec prawidłowości w dynamice, „Organizacja i Kierowanie”, nr 2.

Stubbs W., Cocklin C. [2008], Conceptualizing a 'Sustainability Business Model', „Organization \& Environment”, vol. 21, nr 2, https://doi.org/10.1177/1086026608318042.

Sułkowski Ł. [2012], Epistemologia i metodologia zarzadzania, Polskie Wydawnictwo Ekonomiczne, Warszawa.

Timmers P. [1999], Electronic Commerce: Strategies and Models from Business-to-business trading, Wiley \& Sons, Chichester.

Venkatesh A., Vitalari N.P. [1991], Longitudinal Surveys in Information Systems Research: An Examination of Issues, Methods, and Applications [w:] The Information Systems Challenge: Survey Research Methods, Harvard University Press.

Voelpel S., Leibold M., Tekie E., von Krogh G. [2005], Escaping the Red Queen Effect in Competitive Strategy: Sense-testing Business Models, ,European Management Journal”, vol. 23, nr 1, https://doi.org/10.1016/j.emj.2004.12.008.

Weick K.E. [1979], The Social Psychology of Organising, Addison-Wesley, Reading.

Zott C., Amit R., Massa L. [2010], The Business Model: Theoretical Roots, Recent Developments, and Future Research, WP-862, IESE, http://www.iese.edu/research/pdfs/ DI-0862-E.pdf.

\section{A Longitudinal Survey of Enterprise Business Models (Abstract)}

The business model has become an ontological being heavily explored in theory and frequently used in the practice of management. Multifaceted understanding is a challenge for today's researchers. It is therefore important to determine how to explore the business model and which methods should be used. I believe longitudinal studies are a key method. The article describes and interprets these studies as an optimal research method for studying company business models.

Keywords: longitudinal survey, business model, paradigm, strategic management. 